\title{
Még 50 év - avagy hogyan teremtsük meg a hatékony magyar urbanisztikát?
}

\section{0 more years - or how to establish an effective Hungarian urban planning?}

\author{
ONGJERTH RICHÁRD
}

\begin{abstract}
ONGJERTH Richárd: várostervező, elnökségi tag, Magyar Urbanisztikai Társaság; 1094 Budapest, Liliom u. 48.; r.ongjerth@mut.hu
\end{abstract}

Richárd ONGJERTH: urban planner, member of the board, Hungarian Society for Urban Planning; Liliom u. 48., H-1094 Budapest, Hungary; r.ongjerth@mut.hu

\section{Visszatekintés - a hazai urbanisztika lassú hanyatlása}

A hazai urbanisztika az elmúlt évtizedben a korábbinál is nehezebb helyzetbe került. Egyre szélesebb körben válik ismertté, hogy a hagyományosnak tekinthetö, főként a területhasználathoz kötött rendezési tervek kevéssé alkalmasak a jövőbeli helyi önkormányzati cselekvések megalapozására, az ezektől elkülönülten, gyakran futószalagon készülő településfejlesztési tervek - településfejlesztési koncepciók, integrált településfejlesztési stratégiák - pedig a legtöbbször nem többek puszta forrásszerző eszköznél, amely az adott ciklus területfejlesztési pályázatainak sikeres beadása nyomán menetrendszerüen megy a fiókba, vagy a soha meg nem nyitott számítógépes adattárolókba. Nem növeli a tervezés és ezzel a szakma presztízsét az sem, hogy az önkormányzati tervezés - legalább hét törvény és sok kapcsolódó jogszabály által meghatározottan - csak kevesek számára átlátható, a tervek helyi csomagja bonyolult, ráadásul gyakran változó, kevés logikai kapcsolattal rendelkezö, összehangolatlan rendszert alkot, amelynek az eredményessége, sőt szükségessége is gyakran kérdéses a helyi döntéshozók számára.

Ebben a helyzetben a hazai urbanisztika legjelentősebb szakmai-társadalmi szervezete, a Magyar Urbanisztikai Társaság (MUT) is egyre nehezebb helyzetbe került. A rendszerváltozást megelőzően klubszerűen funkcionáló, egyfajta szakmai „kibeszélő helyként” működő szervezet jelentősége a változások után, a teljes szólásszabadság megvalósulásával, a különféle szakmai mühelyek számának gya-

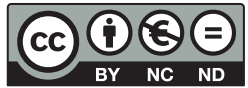


rapodásával, a begyakorolt tervezési sabloneljárások elterjedésével lényegesen csökkent, ami a tagság folyamatos és jelentős fogyatkozásában (1990-2015 között az egyéni tagság tekintetében 600-ról 100 före) is megmutatkozott. Különösen fájó „spontán indikátora” a MUT sorvadásának a fiatal szakemberek taglétszámának alakulása. A társaság viszonyait folyamatosan figyelő elnökség olyan kettős, hosszú idő óta tendenciaszerü folyamatot figyelhetett meg, amely szerint a tagfelvételi kérelmeket tekintve a társasági tagság vonzónak mondható a frissen végzett hallgatók, pályakezdő szakemberek körében, akik azonban egy-két év után „kikopnak" a díffizető tagság köréből, illetve tényleges aktivitás hiányában be sem kerülnek oda, így érdeklődésük a jelenlegi viszonyok között nem fenntartható.

\section{A megújulás első kísérletei}

Ilyen körülmények között úttörő szándékkal indult 2009-ben a MUT 2000-ben létrehozott és akkoriban innovációs központtá alakított Magyar Urbanisztikai Tudásközpontban (MUTK) az urbanisztika gyakorlásának problémáit, a meglévőnél hatékonyabb, a célközönség számára vonzóbb módszereit feltáró kutatássorozat. A sok - az akkor illetékes kormányzati szervek megbízásából és finanszírozásával végzett - helyszíni felmérés és mühelymunka nyomán 2012 tavaszán az önkormányzati tervezési rendszer korszerüsítésére vonatkozó javaslatcsomag is összeállt az akkor illetékes helyettes államtitkárság részére, amely szándékaink szerint lényegesebben egyszerübbé, logikusabbá és átláthatóbbá tehette volna az önkormányzati tervezés eljárásait. Ezt a változtatást azonban az akkor kompetens vezető tisztviselők nem vállalták fel, hanem ehelyett megalkották - hosszú és körülményes címe szerint - „a településfejlesztési koncepcióról, az integrált településfejlesztési stratégiáról és a településrendezési eszközökről, valamint egyes településrendezési sajátos jogintézményekről” szóló 314/2012. (XI. 8.) kormányrendeletet. Ez a jogszabály részletes - és nemegyszer ellentmondásos, következetlen - előírásrendszerével alkalmas volt arra, hogy a szakmailag kevésbé felkészült szakmagyakorlók és a saját pozicionális biztonságukat kereső foeépítészek számára megfelelőnek vélt támaszt adjon, arra azonban értelemszerüen nem, hogy népszerübbé, elismertebbé és nélkülözhetetlenné tegye a területi tervezést a szakmával érintett kívülállók - pl. döntéshozók, civil szervezetek vagy az egyszerü állampolgárok - szemében.

\section{A „sorozatgyártott tervezés” - a szakma mélypontja}

Nem segítette a szakma presztízsének javulását az a 2013-2015 között lefolytatott kormányzati akció sem, amelynek keretében központosított, régiónként le- 
folytatott közbeszerzés nyomán az ország mintegy 150 járásközpontjára rendkívül nyomott áron és nagyon szűk határidővel új integrált településfejlesztési stratégia készült, ahelyett, hogy a korábbi integrált városfejlesztési stratégiákat vizsgálták volna szükség szerint felül. Ez a nagyszabású, sok százmillió forintos akció megerősítette a tervezéssel közvetlenül érintett helyi döntéshozók szemében a fejlesztési tervek formális, forrásszerző szerepét, ugyanakkor az országosan kiválasztott öt konzorcium által a gigászi munkába bevont mintegy 80-100 szakember kevéssé tudott az egyedi követelményekhez maradéktalanul alkalmazkodó terveket készíteni. Ez a tény az urbanisztikai szolgáltatások, a tervezés elsődleges célcsoportját jelentő önkormányzatok körében tovább erősítette a „szükséges rossz" érzését, ami viszont ismételten csökkentette a szakma presztízsét.

\section{Új törekvések a MUT környékén}

A MUT elnökségében és a MUTK műhelyében ezzel párhuzamosan tovább folyt a munka a MUT új, az eddiginél vonzóbb, hasznosabb szerepének, tevékenységeinek megtalálására és beindítására. A MUT elnöksége 2013-ban fogadta el a MUTK „innovatív portfóliónak" elnevezett tevékenységcsomagját, amelynek keretében a cég a gazdaságorientált, megvalósuló várostervezés jegyében olyan új, de NyugatEurópában már bevált tervműfajokat alakított ki és próbált bevezetni a tervezési piacra, mint a belvárosok újraélesztését szolgáló üzletutca-fejlesztési terv vagy a települések vonzerejét, turisztikai attraktivitását növelő települési örökséggazdálkodási stratégia. 2016-ra a Tudásközpontnak mind az öt új, innovatív termékre sikerült a megrendelő önkormányzat által elfogadott referenciát szereznie.

A MUT 2016 végére jutott el oda, hogy komolyan szembenézzen a saját helyzetével, amikor professzionális szervezetfejlesztő szakember közremüködésével az év novemberében négy nyilvános műhelyvita során a tagság köréből érkezett résztvevők felmérték a társaság adottságait, lehetőségeit, és javaslatokat dolgoztak ki a társaság új szerepkörére, szolgáltatásaira. Az így elkészített stratégiában kiemelt szerepet játszott a MUT új feladataként az urbanisztika tevékenységi körének lehatárolása, az urbanisztikával hivatásszerűen foglalkozó szakemberek számára a szakma teljességét felölelő szakmai követelményrendszer felállítása, az egyes tudásterületek tartalmának meghatározása és a követelményeknek való megfelelőséget megállapító eljárások meghatározása.

\section{Tervidőszakok - kapcsolatfelvétel a brit RTPI-jal}

Ezzel párhuzamosan, 2015 kora nyarán jelentkezett a MUT-nál az évek óta Skóciában élő és dolgozó fiatal urbanista, Láposi Roland - korábban az Ecorys Ma- 
gyarország Kft. munkatársa - azzal a felajánlással, hogy szívesen lefordítaná az Európa-szerte jelentős presztízzsel rendelkező brit várostervezői szervezet megalapításának 100. évfordulójára megjelentetett „Tervidőszakok” (Planning Horizons) kiadványsorozat első füzetét, a „Térben gondolkodva” (Thinking Spatially) című kiadványt, ha a MUT felvállalja a hivatalos kapcsolatfelvételt a szerzői jogok birtokosával, az RTPI-jal, és vállalja a tervezett e-kiadvány terjesztését, promócióját. A MUT elnöksége támogatta a javaslatot, és az RTPI részéről Richard Blyth közreműködésével együttműködési megállapodás jött létre a két szervezet között. Ezt követően Láposi Roland és Zsigmond László lefordította a kötet szövegét, és a MUT 50. születésnapján, 2016. február 4-én a MUT nagytermében sor került a kiadvány magyar e-könyvként való bemutatójára. A rendezvényre Budapestre érkezett Phil Williams, az RTPI akkori elnöke, és a két szervezet megállapodott abban, hogy az ECTP (Európai Várostervezők Tanácsa) keretén belül kialakult együttmúködésen túl kétoldalú aktivitásokkal is segítik a hazai urbanisztika fejlődését.

\section{még50év}

A sikeres rendezvényt követően Láposi Roland - Zsigmond László mellett SoókiTóth Gábort és Vajdovichné Visy Erzsébetet is bevonva a munkába - lefordította a Tervidőszakok sorozat másik négy füzetét is, és ezek bemutatására a MUT megbízásából a MUTK 2017. február 24-én, a MUT 51. születésnapját ünnepelve megszervezte a még50év címü konferenciát, ahol az RTPI soros elnöke, Stephen Wilkinson mellett hazánkba érkezett Richard Blyth és több RTPI-tag is. A konferencia mellett megszervezett találkozók során a két szervezet vezetői megállapodtak abban, hogy megvizsgálják a lehetőségét annak, hogyan lehetne a gazdag brit tapasztalatok hasznosításával felállítani az új magyar várostervezői követelményrendszert.

\section{Várostervezők európai minősítéssel? - A MUT új szerepben?}

2017 márciusában az Európai Várostervezők Tanácsának elnöke véleményezésre megküldte a MUT-nak a nemzetközi szervezet által kidolgozott és a nyári közgyűlés számára elfogadásra előterjesztett tervezetet az európai várostervezők kompetenciakövetelményeiről, amely összhangban van a brit követelményekkel is, bár annál szélesebb tudásanyagra terjed ki. A két tervezet alapján 2017 májusában indul el a MUT-ban az a mühelymunka, amely a szervezet égisze alatt az európai követelményeknek megfelelően, az urbanisztikai képzésre vállalkozó felsőoktatási intézmények bevonásával dolgozza ki a hazai városter- 
vezői kompetenciakövetelményeket. Ezt követően kerülhet majd sor a részletes tantervi követelmények, minősítési eljárások kidolgozására és különféle kurzusok szervezésére, ahol a jelentkezők elsajátíthatják a szükséges ismereteket, illetve szükség szerint kiegészíthetik azokat.

Ennek sikere - a folyamat szervezői szerint - jelentős lépés lehet a nagy múltú szervezet jövőálló fejlesztése szempontjából, reményeik szerint biztosítva annak további legalább 50 éves fennmaradása mellett a hazai urbanisztika sikerességének, elismertségének lényeges javítását és - a kompatibilis követelmények kapcsán - a hazai urbanisták kompetenciájának és presztízsének európai színvonalúra emelését is. 